\title{
Promises of climate engineering after neoliberalism
}

Nils Markusson, David Tyfield, Jennie C. Stephens and Mads Dahl Gjefsen

\begin{abstract}
The apparent, if uncertain, rejection of neoliberalism manifested by the election of Donald Trump in the US (alongside the slim, but clear majority for Brexit in the UK, and a growing racist and protectionist nationalism across Europe) necessitates renewed analysis of the future of both promises of technical fixes to climate change, such as carbon capture and storage (CCS), carbon dioxide removal (CDR) and solar radiation management (SRM) (in this chapter collectively referred to as climate engineering), and the potential future hegemonic political regimes that may replace neoliberalism. Drawing on a cultural political economy analysis of the co-evolution of political regimes and promises of technical fixes to climate change (Markusson et al. 2017), we here discuss what the current moment of radical destabilisation might augur. The election of Trump indicates a potential unsettling of an established dynamic whereby promises of technical fixes to climate change co-evolved with, and imperfectly supported, the neoliberal power regime and its preferred marketbased solutions to the climate change problem. We identify two key and interacting dialectics, between neoliberalism and illiberalism, and between continued neoliberal (but illiberally challenged) US hegemony and budding China-centred liberalism 2.0. Both these dialectics appear conducive to prolonged attention to the promise of climate engineering, as talk and research, or even as limited deployment.
\end{abstract}

\section{Introduction}

The political landscape surrounding issues of climate engineering is currently changing fast with the rise of new nationalist populism across the US and Europe. What do these latest developments suggest for the future envisioning, development and deployment of climate engineering? How could this technology develop in interactive parallel with a changing political regime? And how can systematic speculation about such futures help us understand the current political turbulence?

In characteristically incoherent fashion (though aligned with other deniers), the recently elected US president Donald Trump has both denied the existence of anthropogenic climate change, and lauded 'clean coal' technology as a means of ensuring continued coal use (Clouse 2016, Schwartz 2017, Faber et al 2017). This position is confusing in its own right. But its implications for climate policy framing and strategy are also unclear. On the one hand, it could be seen as a good fit with the established pattern of neoliberal climate change policy. Neoliberal climate policy has been characterised by reliance on emissions markets, and shored up by promises of climate engineering technology: technical fixes to climate change, primarily carbon capture and storage (CCS), and also more recently explicit climate engineering through carbon dioxide removal (CDR), and, though less so, solar radiation management (SRM). To date, climate policy in the neoliberal regime has only developed weakly-performing emissions markets that do not threaten fossil-dependent industry, nor implementation of climate engineering technology (Markusson et al 2017). Marketizing the atmosphere through emissions trading has been the quintessential neoliberal stance (Lohmann 2012; Quiggin et al, 2014) and entailed an ambiguous position that superficially acknowledges climate change as an object worthy of a policy response, whilst at the same time denying its reality as a systemic crisis. In this sense, the particularities of Trump's incoherence are merely an extension 
and enhancement of a longstanding and deeply sedimented neoliberal tension in the climate policy arena.

But there may be a more fundamental shift on the horizon. Trump has also departed from key neoliberal policies in the form of cancelled trade deals, and even evoked fears that his ascendancy represents a resurgent illiberalism (see e.g. McDougall 2016), e.g. through his challenges to the judiciary in the context of immigration policy, and in his open nepotism giving prominent positions to family members in the administration. Trump has not (yet, at least) mentioned climate engineering, but there are prominent people in his administration that are long-term supporters of such technology (Lukacs 2017, Bajak 2018). This potential of the Trump administration to look favourably toward climate engineering resonates with warnings of inherent illiberalism of some SRM type technologies (Macnaghten and Szerszynski 2013).

Trump is now the elected leader of the hegemonic country of the current world order. But his election should also be seen, together with Brexit in the UK and a growing European racist populist nationalism, as indicative of a direct challenge to neoliberal globalisation from across the global North, as well as of the (longer process of) decline of US hegemony (Wallerstein 2003). In all these respects, these seemingly epochal developments can also be seen as the products of neoliberalism itself - its bastard offspring - as, of course, is Trump himself, the asset-stripping property magnate and agnotological post-truth, social media-trolling celebrity, as archetype and epitome. Trump is thus a continuation of neoliberalism but also entirely dependent on wide-spread re-action against neoliberal globalisation, and so embodies the turbulence of political economic epochal change, signifying the transition to a new regime. Such a shift of the tectonic plates of the political economy must surely also have profound impacts on - or rather co-evolve tightly with - the future of the development of a technological intervention as politically controversial and consequential as climate engineering (Keith 2017). Under this new and dynamic regime, the promises of technical fixes to climate change in the form of climate engineering (CCS, CDR and even now SRM) are being renegotiated.

We are, it seems, living through a time of systemic turbulence, when dialectical tensions are erupting and becoming manifest at accelerated pace. At the level of transformations in the political economic regime dominating global society (and so, for the time being, global capitalism), we see two such overlapping and interacting dialectics playing out in the late 2010s. The first of these concerns precisely the creative destructive interplay of a still-dominant, if non-dead (cf. Crouch 2011), neoliberalism and the rise of its illiberal progeny, fuelled precisely by the increasingly selfdestructive dysfunction of the former. This is a development equivalent, but crucially different in substance, to the global conflict of a failing British imperial liberalism and the rise of fascism in the 1920s and '30s (cf. Fuchs 2017).

In the US, at the heart of the disintegrating neoliberal world order, neoliberal certainties, such as the infallibility of 'the market' that were previously politically radical and strategically effective precisely as such, are increasingly trapped in a double bind whereby they are either without opposition from 'serious' opinion and/or have lost popular credibility, in particular as proposed solutions to the key issues of the day, including economic stagnation and underemployment. The politically radical dynamism of neoliberalism, upon which that regime is founded, is thus neutralized, and even rendered to seem inadequately radical, especially as it is challenged by bold illiberal actions (even as these are themselves sometimes reined back in). This is evident in the climate policy arena, where Obama-era commitments to climate mitigation and the UNFCCC Paris Agreement have been dismissed with a roll-back of power sector emissions regulation (The Clean Power Plan) and withdrawal from the Paris Agreement, while climate denialism has been bolstered and 
mainstreamed (Smith 2017, Volcivici et al. 2017). A particular form of stable (if arguably stagnant) policy, based on an entrenched, if contested, mix of economic dogma, climate science and promises of technical fixes, has been juxtaposed with the instability of rash political gambits, disregard for science and heated controversy.

Disparate articulations of the future of CCS and climate engineering are part of this dynamic. In the spring of 2017, op-eds in The Guardian speculated about whether the Trump administration's roll back of climate policy will make climate engineering seem more urgent, whether Trump may come out in favour of climate engineering (rather than opt for full-on denialism), and whether climate engineering researchers would accept the Trump administration's support given its links to climate denialism (Lukacs 2017, Keith and Wagner 2017). All of this, however, points to the second dialectic: namely regarding the damage done by all this domestic political transformation in the US to its global domination, and the possible rise in its place of a new polity at the centre of $21^{\text {st }}$ century capitalism, the only viable candidate being China. Again, of course, this second dynamic has parallels in the 1930s, concerning the decline of the Pax Britannica and the ascendancy of a (reluctant, at time isolationist) American hegemon. We discuss this second dynamic below in terms of the stillembryonic exploration of climate engineering in China, there under very different political and sociocultural circumstances and approaches to those pursued to date in what has been an overwhelmingly Euro-American debate.

This chapter thus aims to analyse the current moment of turbulence, with regard to the ongoing coevolution of the (geo-)political regime and the deployment potential of climate engineering as supposed technical fixes for global climate change. Informed by previous analysis of the cultural political economy of promises of technical fix to climate change (Markusson et al 2017), we will here discuss possible co-evolutions of the political regime (neoliberal, illiberal and other scenarios) with climate engineering technology. We will also discuss the current dialectic between the lingering neoliberal regime and the illiberal upstart, and between continued neoliberal US hegemony and the rise of an alternative China-centred regime, and how the promise of climate engineering is implicated in these dialectics. We are here concerned with how best to understand the 'contemporary hinge' (cf. Ryghaug and Moe Skjolsvold 2010) between the past of a neoliberal regime shored up by climate engineering promises, and multiple potential futures of the political regime co-evolving with climate engineering.

\section{The cultural political economy of promises of technical fixes to the climate change problem}

In previous work, we developed a cultural political economy framework to analyse promises of technical fixes to the climate change problem (Markusson et al 2017). We argue that the dominant neoliberal regime resulted in a persistent non-implementation of CCS, CDR and SRM. We analyse how technology, both as rhetorical promises and as substantial development and deployment, coevolves (non-deterministically) with political regimes. Promises of new technology may justify new spatio-temporal fixes for capital to invest in and hence new industries that can underpin political regimes. In turn, political regimes may favour the kinds of technology that can support their underpinning industries. As long as a contingent and emergent cycle of positive reinforcement can be maintained, technology and political regimes can co-evolve in a mutually supporting, dynamically stable pattern of interaction.

Moreover, we distinguish between ordinary and defensive spatio-temporal fixes, where the latter's main benefit is one of defending the former in the face of threats. For example, whilst CCS 
technology has some potential to generate profit and growth in its own right, it is more important economically in its potential to defend existing and future fossil fuel based operations across a range of industries in the face of the climate mitigation imperative. It is in this sense a defensive spatiotemporal fix, and the promise of CCS technology is the promise of a technical fix to the climate change problem while leaving existing socio-technical and political economic energy systems substantially intact.

A large and ever-growing literature has detailed how the history of roughly the past four decades, up to and possibly including the new age of Trump, has been dominated by a neoliberal political regime. By this we mean a political regime that is at its core an epistemic project, organised around a belief in the unlimited capacity of markets to determine the optimal allocation of all things, including societal attention to ecological and other problems, and the conceptual prioritization of policies that support economic growth and overcome barriers to growth (Mirowski 2013). These neoliberal commitments have impacted on how knowledge production is organised and how it shapes social change. Specifically, the neoliberal regime has favoured short-term financial profit making over longterm infrastructure investment, privately appropriable profits over public goods and opportunistic, venturesome exploitation of (possibly existing) assets over innovation of radical new technologies (Tyfield 2016). The neoliberal regime has thus engendered a reorganizing of society, technology and industry and the creation of new winners and losers that has empowered ideological cheerleaders that then support further neoliberal policies, thus setting up positive feedback loops.

Moreover, the neoliberal regime, with its commitment to limitless markets and unlimited growth, propagates an illusion of resource inexhaustibility, as exemplified by the economics of oil (Mitchell 2011). In dealing with climate change as a problem, and potential barrier to continued economic growth, the neoliberal regime has unsurprisingly turned to economic instruments in the first instance, with emissions trading as the emblematic policy instrument. This has then been married with the promise of CCS technology, which helped fossil-fuel invested climate deniers acknowledge climate change and envision a future of both continued fossil fuel use and climate mitigation (Stephens 2014, 2015). The promise of CCS, therefore, has perpetuated the neoliberal political economy regime, which underlies the ever-more pressing climate change imperative (Markusson et al 2017). Moreover, within the neoliberal political regime which promoted CCS in the 1990s and 2000s, the CCS promise helped to make economic instruments like carbon taxes or carbon trading palatable to countries in the Global North whose climate ambitions clashed with dependence on fossil fuel extraction, e.g. the US and Norway (Stephens 2009). Internationally, the outcome of this process is that neoliberal climate policy has by and large failed, and has had limited impact on industry generally, and on CCS investment specifically. Emissions trading schemes have either not been introduced, or been allowed to generate prices too low to reduce emissions meaningfully. Reiterating the promise of CCS, while supporting limited research, has been more palatable to governments around the world than actually investing in expensive CCS demonstration plants (Markusson et al 2011). The simultaneous ongoing failure of the neoliberal regime to implement more than a few CCS facilities and continued reliance on the promise of CCS in climate modelling, shows that the CCS promise has worked to support the regime precisely and only by remaining a promise (Markusson et al. 2017). Significant public investment in innovation and infrastructure would run directly counter to the policy prescriptions of CCS's most powerful, i.e. neoliberal, supporters.

It is within this neoliberal context that the practical and imaginary conceptualization of climate engineering strategies have emerged. The trajectory of CDR appears to be following in the footsteps of CCS. As the CCS promise turned into disappointment (Shackley and Evar 2012; Martínez Arranz 
2016), and the climate change crisis worsened, the policy gaze has turned to CDR technology, especially bioenergy with CCS (BECCS). Like CCS, CDR is now positioned as a promise of a technical fix to align climate mitigation with economic growth, by (like CCS before it) allowing the construction of scenarios with limited warming alongside continued fossil fuel use that is largely unchanged. CDR has thus emerged as (for now at least) a fresh neoliberal technical fix promise that has yet to be checked by experience of (a lack of) implementation, and as such is valuable to the regime. Like CCS, it may be most valuable to the regime as a promise, and that does not bode well for CDR development and implementation, but rather suggests a repeat of the CCS interlude.

In contrast, the promise of SRM has not aligned well with the neoliberal regime. SRM has been depicted in high-profile reports as beyond the pale, and surprisingly unfit for inclusion in marketbased policy solutions (Royal Society 2009; IPCC 2014). It has been presented as both physically dangerous, with unpredictable, potentially disastrous side-effects on the climate system, and politically problematic (indeed illiberal) in that it may require globally centralised decision making that would be hard to check democratically. It has thus served to signpost a limit to acceptable neoliberal technical fixes, and so also as a threat of what transgressions necessarily await if we don't support and implement the acceptable fixes. But, when relegated to being an external disciplining force, the promise of SRM has also challenged the foundational neoliberal belief in the unlimited ability of markets (and market instruments) to overcome barriers of change. For the very proffering of a distinction between such acceptable and unacceptable technologies is precisely to concede the independent existence of 'limits'; a profoundly destabilizing eventuality for neoliberalism as a whole. The dynamic of the neoliberal regime, which admits no obstacles or constraints and revels in its destruction of 'sacred cows', unfolding with repeated promises of technical fixes for climate mitigation thus seems to have met a real - and so, as such, potentially fatal - stumbling block. That said, SRM could yet be embraced by neoliberalism as an extreme state intervention necessary to make market solutions to climate change work. If this happened, we might then envision the introduction, in turn, of competition and privatisation, to extract whatever rents are possible on the back of such a state intervention. So far, though, such state intervention has been deemed excessive, and no alliance has been created backing this alignment of state-SRM with emissions markets.

In previous work, we used our analytical framework to speculate systematically about possible futures, resulting from plausible co-evolutions of a political regime with promises of climate engineering as a technical fix to climate change. We sought to assess what evidence there was for each. Looking back, those scenarios already need updating, which tells us something about the turbulence of the current moment (just after the election of Trump, the Brexit referendum, etc.), and the unfolding evolution of both the current political regime and climate engineering, which may be going through a moment of radical rapid change. A key rationale for writing this chapter is the illiberal tendencies of recent times and their challenge of the incumbent neoliberal regime (e.g. Economist 2018a), but we are well aware that the future is more radically open-ended than that dichotomy suggests. In the following section, we will first elaborate on the range of scenarios, to show some of the variety of multiple futures that are possible for co-evolving climate engineering and political regimes. In the fourth section, we will use those scenarios to shed new light on current affairs. 


\section{Future scenarios}

Here we identify three distinct scenarios: (1) a continued neoliberal regime, (2) an illiberal regime and (3) an emergent 'liberalism 2.0' centred on China. These may be succinctly distinguished in terms of which fractions of global capital are dominant in each case (e.g. Gill and Law 1989, Robinson and Harris 2000). In the neoliberal regime, globalised finance capital continues to dominate productive capital (both the automobile, consumer electrics etc. fraction underpinning US hegemony, now also globalised, and the more recently emerging digital economy). The illiberal scenario entails a retrenchment of the domination of finance capital, but now firmly dependent upon illiberal state power - in a new (un)Holy Alliance -, and hence divided up into national factions that incubate a global geopolitical context of tension and possibly conflict. Here, then, US global dominance is even more flagrantly a situation of sheer 'domination', not even clothed in the velvet glove of 'hegemony' (Arrighi 1995). In the liberalism 2.0 scenario, a new productive capital fraction based on the digital economy takes centre stage, with China, where many of these businesses are already in evidence, as a new hegemon.

For each scenario, we will discuss both the potential evolution of the political regime and speculate about the fate of climate engineering (as promise and as implementation). We draw on our analytical framework for the co-evolution of technical fix promises and political regimes and our previous work on the history of neoliberalism and climate engineering. To demonstrate how each scenario might evolve from tendencies in the current turbulent state of affairs, we will also mobilise supporting evidence about the current situation for each scenario. The time frame envisioned for the scenarios to unfold is $15-30$ years.

\section{(1) Continued Neoliberal Regime}

It is possible that the current drama around Trump and Brexit ends up being only a minor upheaval that neoliberalism takes in its stride. In the US, Trump's private economic interests may come to override his right-wing-populist political positioning (Faber et al 2017). Several commentators suggest that his politics, especially domestically, is in fact predominantly neoliberal, with, crucially, a friendly relationship to Wall Street and the financial sector (Hutton 2017, Palley 2017). To the extent that Trump himself actually leads an administration of untrammelled Republican dominance, were he to be removed from office, a Pence administration may also shed some of the more outrageous populism and double down on just such a renewed and newly ruthless neoliberal agenda. This would involve a frank celebration of inequality but where the very Prometheanism of such 'winner-takesall' competition turns out itself to elicit breakthroughs to big new horizons of profitable investment profiting from, not just in spite of, the current political and environmental turbulence - that enable a new wave of economic growth that relieves and/or distracts from populist grievance somewhat. For instance, in the UK, key industrial sectors, including finance, may well find ways to profit even from Brexit, and help sustain the neoliberal political regime (Jessop 2017).

In this scenario, neoliberalism survives the current nationalist, protectionist challenge, resulting in renewed commitment to free trade and continued globalised financialisation of the economy. Since the last couple of decades have also seen spectacular growth across most of the world, with the only clear winners being the working and middle classes of the global North, global appetite for such a regime is also eminently plausible. De-regulation and privatisation thus continue to be priorities, and market instruments continue to be seen as the solution for any issues by intra-national elites across 
the world. The 'success' of a further kickstart in economic growth would also serve to vindicate, and so strengthen, core neoliberal beliefs in the limitless primacy of market-based entrepreneurialism; which would, in turn, feed into a rejuvenated positive feedback loop between fossil fuels, especially oil and gas, and (belief in) unlimited growth(Mitchell 2011, Tyfield 2014). Meanwhile, international commitments to climate change policy would likely evolve, but remain ineffective and insufficient.

In light of the history of the co-evolution of neoliberalism with the promises of climate engineering, with this scenario we would expect continued non-implementation of climate engineering. The carbon price signal would remain weak, and current promises remain stable for some time, with continued interest in CDR technology, and CCS rumbling along weakly in the background. SRM would most likely remain out of bounds, beyond perhaps some limited research, but a resurgent concentration of power in neoliberal hands could in time reopen exploration of this possibility too, now able to sweep objections aside. As this could, in turn, further concentrate forms of economic and environmental power, particularly in terms of opportunities for private profit-making from the privatization of climate engineering initiatives perhaps initially introduced at state level, this could also set up new positive feedback loops of deepening co-production with a rampant neoliberalism 2.0. Key to such a scenario, however, would be the re-emergence of new dynamics through which finance capital would once again be able to profit from, and so be progressively unified and empowered by, the growth of markets, market-based technologies and technological fixes, and the problems they themselves instigate.

How this scenario may play out in the longer-term, as the climate crisis - or, indeed, the instability of the global economic system through ever-deeper financialisation and concentration of wealthescalates and puts pressure on the regime, is unclear. As climate impacts worsen, the regime will probably face escalating carbon prices. Yet whether or not these are fundamentally destabilising or simply feed further neoliberalisation would depend on just how effective (global) neoliberal forces have been in further concentrating power in their hands in the meantime. After all, neoliberalism has weathered many seemingly 'fundamental' destabilizations over the last few decades, precisely insofar as it can invert such conjunctures into opportunities for profit. If successful, then, high prices could conceivably be readily accommodated by the wealthy (both individuals and corporations) while simply forcing the costs on others who cannot afford them but have inadequate resources to resist further worsening of their situation; i.e. a further exacerbation of inequality that may be troubling in itself, but is not per se for neoliberalism. Here, then, a neoliberal 'solution' to climate change may even ultimately emerge (as discussed above), but at the cost of ever-worsening economic and political inequality. In this scenario, we could see implementation of climate engineering technologies.

\section{(2) Illiberalism}

Another possible scenario emerges from the possibility that the illiberal tendencies of increasing numbers of national leaders go unchecked. Their appeals to nationalism and strong leadership leads to continued high levels of right-wing populist support for narrowly focused, nationalistic policies (McDougall 2016, Faber et al 2017) emboldening the illiberal elements of the Trump administration - or, again, the Republican government that would remain in place and accountable to its angry populist base even where Trump himself is removed from office. Here we could imagine a sustained and successful strategic effort to weaken and conquer the judicial and legislative branches of government on top of the all-out assault on administrative arms of government working in the 'public interest' or for social welfare, notably environment, energy, science and education. 
In this scenario, and in contrast to the neoliberal regime, the governance epistemology is not that of a market, but that of a dictatorship characterized by fear, nepotism and corrupt networks of personal enrichment playing out a populist politics of anti-'liberal' outrage. The market is tolerated and perhaps even celebrated in discourse, at least domestically, but in practice market liberalism is only allowed when it does not challenge the leader's fancies, family and friends. It must be noted, of course, as flagged above in terms of the 'bastard offspring', that this is in a sense an extension of neoliberalism which has long concentrated power in individuals and corporations (and networks thereof) under its banner of freeing the supposedly impersonal and disinterested market (Crouch 2011). Notwithstanding this important continuity, however, the flagrant abuse of power and whipping up of socio-cultural division and animosity marks an important discontinuity and difference in this scenario to that just considered above.

The utter dominance of finance capital over productive capital is here broken, but primarily due to the weakening of the former, weighed down and split by its own internal contradictions, not the strengthening of the latter. Instead, a third actor, namely the nation-state, steps in to fill the power void. In particular, a novel coalition emerges between illiberal forces, taking the reins of state power, and the sympathetic elements amongst the existing powers of a now-threatened financial elite. This coalition drives a programme that aims to preserve its privileged status amidst the disintegration of the neoliberal order through systematic dissimulation, concealing its elite, selfserving agenda beneath a banner of populist grievance and the sowing of division.

Such an approach would include the promise of reviving industries, and associated fractions of productive capital, from an erstwhile heyday (e.g. of US hegemony, but consider also Russia or Turkey etc...). Globalisation would also be rolled-back, and national capital factions strengthened. Industry serving the military (a key priority, connecting concentrated authoritarian power and populist jingoism) or providing means of popular surveillance provides stable jobs, possibly alongside construction and realty sectors benefitting from large infrastructure investments in which the populist leadership are themselves predominant creditors (Smith and Voss, 2016). We might even see re-shoring of industries (cf. Waldmeir, 2018). Since there is already evidence of this development, what is key is the plausibility of a dynamic for its continuation over the medium-term: as deepening illiberalism in government action feeds greater turbulence, which both further challenges the capacity of finance capital to fashion the world in its preferred image while also offering multiple and growing openings for opportunistic profit-making (of the kind finance has perfected under neoliberalism), thence deepening the social and political crises that underpin further populist anger.

All in all, it is less productive as a capitalist regime, although an initial investment boom may give it a temporary boost. In perhaps marked distinction to the continued neoliberal scenario, where the growth of renewables driven by corporations and market forces continues, here society deliberately and defiantly still runs on fossil fuels, potentially with an added renaissance for centralising nuclear power. Trump's defence of the coal industry and coal jobs (Clouse 2016, Schwartz 2017) leads to some resurgence in coal mining and use in the US, while all 'unconventional' sources of oil and gas are developed, regardless of environmental impact or even the economics of a 'business case'. The powerful global influence of the Trump administration through the enduring levers of US power, including dollar seignorage and unrivalled military firepower, conditions parallel unravelling of liberal democracies throughout the world, not least through support (whether moral, as exemplar or more actively engaged) for insurgent populisms within these countries as well.

This illiberal scenario appears compatible with the evolution of multiple different outcomes for climate engineering. Defence of coal may evolve alongside continued, successful denial of climate 
change, and therefore little reason to support climate engineering. But, under an illiberal regime, there is also scope for autocratic use of climate engineering, especially SRM. The centralising quality of some SRM technologies has reasonably made many observers wary of their democratic consequences (e.g. Macnaghten and Szerszynski 2013), and there have been warnings that climate engineering with global consequences could be undertaken not through international cooperation but by single actors. Victor (2008) warned that a wealthy 'greenfinger' person could deploy some climate engineering technologies. Clearly, an autocratic leader of a rich nation could unilaterally deploy SRM technology.

An unaccountable, unreliable 'strong leader' could deploy SRM on a whim, but deployment could also be quite strategic. SRM could be justified by a leader or a group of leaders as a means to benevolently reduce the suffering of some of the world's most vulnerable people. However, in practice, controlling the distribution of climate impacts is surely going to be extremely challenging, perhaps impossible, and would come with a serious risk of leading to international conflict. The military potential of SRM technology (Fleming 2010) might also be attractive to a unilateralist nationalist leader, backed by a strong military industry. Climate emergency might be invoked as an excuse for developing weaponised climate engineering technology, and could have the added benefit of projecting an image of strong leadership befitting a populist leader, feeding populist opinion, fear and support on which such a regime would depend. Climate engineering technology may also be used for domestic weather controlling reasons, but if so it is likely to spill over into regional conflict, and so again have military implications. The decision to take unilateral national climate engineering action here thus correlates with a growing geopolitical climate of great power tension and bluster, as only such military powers would (believe they) have the capacity to ignore global pressure to consider implications on other countries. Yet, conversely, amidst growing lack of global cooperation (including on climate change) and heightening geopolitical antagonisms (exacerbated by worsening differential climate change impacts), unilateral (and possibly weaponised) climate engineering becomes more likely.

\section{(3) Liberalism 2.0}

The election of Trump may also signify the descent of the US as hegemon. Trump's promises to make the US as strong as it once was, as in his campaign slogan to "Make America Great Again", can be interpreted as widespread popular recognition, not least in the US itself, that its global reign is weakening. The phenomenal growth and current size of the Chinese economy, including in emerging digital and knowledge economy sectors, suggests that Chinese ascendancy and the Chinese capitalist regime are critical determinants in the future world order (e.g. McNally et al. 2013, Tyfield 2017a, cf. Hung 2016, Fenby 2016). Trump's early foreign policy has been erratic, but he repeatedly denounced China in his presidential campaign regarding its negative economic impact on the US and clashes with China have already emerged, notwithstanding attempts to court the Chinese President Xi Jinping. This may reflect friction in the process of global realignment.

Tyfield $(2014,2017 a)$ has discussed the possibility of a qualitatively novel future liberal regime, centred on China, that marks a different combination of continuities and discontinuities from the neoliberal regime to those of the other two scenarios above. This involves the turbulent emergence of a revitalized regime of the classical laissez faire liberalism, but refitted for the age of wicked problems and complex systems (and sciences thereof) - including, of course, climate change itself as against the overweening epistemic confidence and belief in 'Progress' of its first incarnation in early $19^{\text {th }}$ century Britain. Like classical liberalism, then, this 'liberalism 2.0' or 'complexity liberalism' 
is characterised by the primacy of individualised negative liberty and a continuing privileging of markets, marking a distinct continuity with the waning neoliberal dominance of the present.

Like the power regime of classical liberalism, it is also characterised by and fuelled by a dynamic of essential contestation. Here embryonic political economic and sociotechnical disruptions (in the $19^{\text {th }}$ century the industrial revolution, today digitization) unsettle previously stabilized political allegiances, producing a political landscape of fragmentation and new polarization. This feeds a relatively lawless growth of the new capitalist economy while the political turbulence and newly vocal 'extremes' forge a qualitatively new political spectrum. This, in turn, constructs a new 'reasonable' political middle of 'liberal' opinion, based on the increasingly empowered winners in this new world of the emergent bourgeoisie of this new capitalist economy. In short, then, under continuing and relatively unchallenged conditions of capitalist political economy, deepening political turbulence serves only to constitute and empower a new and specifically liberal capitalist historic bloc, even as the reins of government may veer wildly to the political extremes along the way.

But there are also important differences to both of these earlier regimes. As against classical liberalism, it is no longer the sovereign individual that stands at the core of this social ontology but the intersubjectively dependent and suggestible networked individual, situated within and constitutive of contemporary complex socio-technical systems increasingly mediated by digital technologies. Understanding of these complex systems, and their potentially turbulent and/or sudden shifts and dynamic disequilibria, thus emerges as the epistemic (and tacitly normative) basis for the argument of the prima facie superiority of unleashing market forces.

But, conversely, rebasing the argument for the market in a new-found body of thought also sets this regime directly against neoliberalism. For this move deposes markets per se from their foundational (and fundamentalist) centrality and re-establishes politically and scientifically compelling arguments regarding not only the possibility that markets may fail in certain instances, but also the offer of guidance on how they may then be fixed. In particular, this then enables a resurgent argument in favour of (possibly 'strong') states rectifying market failures, perhaps through strong regulatory intervention and public ownership of infrastructure. Certainly, government and the state itself thereby receive a renewed legitimacy and mission, in terms of being the agency responsible for managing the stability and resilience of the 'system' (at whatever territorial scale) as a whole. Clearly, this could readily enable a renewed and newly legitimate project of public investment in energy and environment, and innovation and infrastructure related thereto, that has been a singular and deliberate absence throughout the neoliberal period.

What is most important about this putative future regime, however, is that this is not merely an abstract speculative possibility, but rather one that emerges from a reading of the ongoing evolution of socio-technical and political change within the presumptive heir apparent for global capitalist hegemony, namely China (Tyfield 2017a). While many pieces of the puzzle remain embryonic or even absent, such is the dynamism in China across the gamut of issues related to questions of the parallel development of political economic regime (national, local and, indeed, global) and innovation - and especially regarding issues of energy and environment, and particularly in the key space of emerging digital innovations in both of these domains - that betting against significant qualitative change in Chinese society and politics in the medium-term seems almost the bigger risk.

Moreover, many of the key elements of this emergent regime are clearly in place and fast developing. For instance, in contemporary China we find a singularly dynamic participative, if pragmatic, social media-based public emerging, concentrated in a buoyant and rising urban 'middle class' and its production-side equivalent of a surging private sector economy, including in digital and 
knowledge economy service sectors. This group also take environmental risks (increasingly including climate change) extremely seriously as day-to-day lived matters of ontological security.

Such concerns, however, and their empowerment with the ascendancy of this power bloc on both national and global stages, do not augur a new universalistic concern with 'saving the planet' in China. Rather, the parallel and interdependent emergence of both concerted efforts on such issues and this particular constituency most likely suggest that dealing with environmental challenges will unfold in ways that systematically privilege the concerns of this emergent socio-political constituency, while neglecting the more numerous majority who remain disproportionately exposed to the risks and dangers of environmental change.

This is thus a systematically duplicitous regime, in which a gloss of environmental and entrepreneurial virtue enables and is enabled by continuing socio-economic inequalities - again, just as the $19^{\text {th }}$ century gospel of liberal 'progress' was co-produced with the development of the regime of industrial capitalism and its unprecedented Dickensian inequalities at home and creeping imperialism abroad. Symptomatic here would be the growth of a narrative of China as 'green saviour', highlighting its world-leading environmental regulation and investment in renewables, while occluding its continued reliance on and investment in fossil fuels, including coal, both domestically and, through its massive investment programme of 'One Belt, One Road', overseas (Walker 2016; Haas 2017; Hao 2017).

In this scenario, then, at least a credible 'patch' of climate engineering technology would be needed, as promise and deployment, while China's already established leadership in production of renewable energy technologies would suggest climate engineering may also become strongly advocated and pursued without reference to fossil fuels. The current remaining interest in fossil CCS and the growing interest in (some) CDRs may thus here be taken up (cf. Weng and Chen 2014) and the technologies developed and implemented to some extent driven by regulation. SRM seems a more distant prospect, but also not inconceivable.

On the one hand, with little interest or expertise in China on SRM evident to date (though see Temple 2017), and with the singular sensitivity to the Chinese government of issues of national sovereignty - issues raised by SRM - there is evidence that China will be reluctant to pursue this technology, seeing it as too dangerous and prone to lead to international conflict (Moore et al 2016). Though more of a stretch, some have also argued that Chinese policy and diplomacy is structurally and/or culturally disinclined either to take the lead in such a hugely controversial global experiment or to play with the 'human-nature' balance with such seeming recklessness. Yet some of these same reasons also suggest that, while not taking a unilateral lead in pursuing SRM, China could emerge as a crucial mediator and negotiator in constructing global experiments and regulations that allow such development and deployment to take place.

Here, in other words, by stressing the break with neoliberal US unilateral dominance that it represents - manifest in both its approach to regulation of climate engineering and in its 'leadership' on climate matters and 'green technologies' - China may yet construct new political feedback loops in which development of SRM, with China as primus inter pares, serves to boost its global (and domestic) political standing precisely as 'green saviour' and responsible global custodian. In this scenario, then, climate engineering (including SRM) may be developed in ways that explicitly distance these technologies from the case for continued fossil fuel use with which they were associated under neoliberalism - perhaps helpfully occluding the continued investment in fossil fuel infrastructures by China in the meantime. As the climate crisis deepens, the uptake of climate 
engineering as discussed above becomes more likely, especially if the impacts are felt strongly in China.

\section{The contemporary hinge}

The three future scenarios above extrapolate observable tendencies in the current situation. Taken together, the scenarios show that the current moment holds the potential for co-evolution of the political regime and climate engineering into different possible futures. This is not surprising, but we can use the specifics of the scenarios to shed light on the structure of the current turbulence, by exploring the relations between the observed tendencies. We are not arguing that the scenarios are the given trajectories, the paths that must be chosen amongst, in a predictive mode analysis - and so we are not seeking to identify choice points. Rather, we discuss relations between scenarios - and the capital fractions dominant in each - as a way of identifying important dialectical tensions in the current moment, and their impact on climate engineering. We use the continued neoliberal scenario as a default or baseline, and discuss its relations with the two other scenarios presented above.

\section{(a) Neoliberalism - Illiberalism}

As discussed above, Trump (alongside Brexit Italy's populist coalition, Alternativ für Deutschland, Le Pen, etc...) can be read as an (immanent) illiberal challenge to the neoliberal regime, but the latter has not simply disappeared or disintegrated. We still see a strongly financialised economy, fuelled by growth in consumer debt (Federal Reserve 2017), with Wall Street influence thus undiminished, i.e. a globalised financial capital faction sustaining US hegemony. The neoliberal regime has also seen the birth of and been sustained by strong growth in ICT giants in Silicon Valley and beyond, getting credit from Wall Street, generating a new generation of tech billionaires (Smith and Voss 2016, Economist 2017) albeit one still thoroughly saturated with the mores, expectations and power relations of neoliberal (venture) finance. The underpinning server infrastructure is fuelled mainly by fossil fuels - lately, increasingly with natural gas. The neoliberal regime has shaped the policies of both the main political parties in the US. However, we now also see some industry support for the Trump administration, with its often illiberal policies (Economist 2018b). This is no doubt in part driven by a hope for further deregulation, tax cuts and privatisation, for example in the climate policy arena. We can thus see a tension between neoliberal and illiberal futures.

Neoliberal climate policy has been shaped in the tension between climate denialism and climate activism (alongside nearly all of climate science). Whilst denialism has a far stronger presence in the Trump administration than it did in the Clinton and Obama ones, and in this sense an improved standing, there is still a broad coalition of actors in support of climate policy, including states, civil society organisations and parts of industry (Sapinski 2015, 2017, Smith 2017), and international pressure (especially after the Paris Agreement).

Trump campaigned on leaving the UNFCC Paris Agreement, but the administration later wavered on this issue. Trump's aides were split on the issue, as is the Republican Party (Milman 2017). Even some big coal companies argued for staying in, with a central argument being to retain a seat at the international climate policy negotiation table (and that their investment planning horizons are longer than a presidency) (Volcovici 2017). A strategy of staying in but doing very little was a possible outcome (Milman 2017), and would have been in line with neoliberal superficial climate policy, even though the Trump administration finally decided to withdraw the US from the Paris Agreement. 
Uncertainty over US climate policy is affecting the perceived prospects of climate engineering. There is speculation that if Trump can't fight off climate policy as an issue, the potentially cheap fix of SRM may start looking attractive to the administration (Porter 2017, Bajak 2017), and likely rather more attractive than expensive CCS facilities that would add to costs of using coal (and gas). Prominent climate engineering researchers have stated, however, that they would not take funding from the administration and would counsel others to do likewise, with the argument to avoid the technology being associated with the denialist elements of the administration (Keith and Wagner, 2017; Keith, 2017) (although others would say that is too late, e.g. ETC 2017).

But, high-profile climate scientists have also warned that Trump rolling back climate change policy may further undermine belief in the adequacy of current mitigation-oriented climate policies, and in turn strengthen the case for (at least researching) climate engineering (Neslen 2017, Porter 2017), which would then have to be funded by others. It is worth noting that the Gates Foundation will likely fund a new, Harvard-based research programme on climate engineering (Keith and Wagner 2017; Neslen 2017), alongside other foundations. An editorial in the San Diego Union-Tribune (2017) went so far as to say that "We call on one or more of the nation's benevolent billionaires to consider privately funding a massive endeavour on the scale of the Manhattan Project to try to geoengineer such a hedge".

Key industries of the neoliberal regime, on Wall Street and beyond, may opt to support climate engineering (at least research) independently of the federal government. This has already happened, but may now ironically get a boost by fears of illiberal denialism (justified with reference to the coal industry amongst others). If, on the other hand, the Trump administration were forced to side with neoliberalism and rejuvenate its climate policy, then it may be tempted to support climate engineering research as a useful promise of a cheap, apparently non-disruptive technical fix. We may even see parallel, competing efforts of the administration and private actors.

The current tension between neoliberalism and illiberalism creates new uncertainty for climate policy, but climate engineering may come out of it rather well. The promise of climate engineering may be useful for powerful actors, both neoliberal and populist, as long as these tensions remain, and support for climate engineering research may reap the benefits of this.

\section{(b) Neoliberalism - Liberalism 2.0}

China has surpassed the US in terms of trade volume, but not yet GDP, and has as yet not the same global reach in terms of military, political or cultural influence. Clearly though, there is a geopolitical tension between the countries. Importantly, as set out above, a new Chinese hegemony might take the form not of neoliberalism (or illiberalism) but of liberalism 2.0 (Tyfield 2014, 2017a). The geopolitical tension is thus also a tension between political regimes.

China appears to be taking climate change increasingly seriously. This is due in part to rising domestic concerns about pollution and environmental harms, and in support of a booming clean tech industry, but also as a way of projecting soft power internationally (Tyfield 2017b). We should remember though that the Chinese economy is strongly coal dependent, and that China exports large numbers of coal plants to other countries especially in its Asian regional neighbourhood (Walker 2016), which might mean China will not take a global leadership role on climate policy (Haas 2017).

This uncertainty over the relative positions of US and China globally, in general, and regarding climate policy in particular, has probably not had much effect on climate engineering prospects so far. But that could now be changing as Trump pulled the US out of the Paris Agreement giving China 
an even better opportunity to challenge the US for climate policy leadership (Wu 2017) while President Xi has made repeated and explicit global statements to bolster China's image as responsible global custodian. China might also want to exploit the rift between the US and Europe on climate (and possibly now even national security), and strengthen its collaboration with Europe on climate in order to bolster its own green credentials, and at the same time tie the continent closer economically and politically.

Whilst there is a track record in China of weather modification (Guo and Zheng 2009; Lui 2017), and a recent national research programme on climate engineering (Cao et al 2015) and CCS research and demonstration, there seems to be little indication of support for SRM deployment. Hamilton (2013) has argued that climate stress could make Chinese people desperate, and a government under pressure might be tempted to deploy cheap SRM in response. However, several commentators see minimal likelihood of Chinese unilateral SRM deployment due to the lack of any significant constituency advocating for it, coupled with the incompatability of SRM deployment with China's strong protection of sovereignty as a principle in international relations (Edney and Symons 2014; Wend and Chen 2014).

If China wants to demonstrate its commitment to climate mitigation, increased support for CCS or CDR technologies seem more likely. This would also seem to be most straightforwardly compatible with a future liberalism 2.0 in terms of somewhat stronger reliance on governmental nature stewardship and regulation limiting the worst excesses of markets and private action and through action by (networks of) private business and/or civil society actors (e.g. energy companies doing CCS or activists and NGOs running afforestation projects, albeit perhaps in both cases in the context of considerable governmental carrots and sticks). Such a model of fiercely competitive and experimental private enterprise taking the lead in constructing new technological capabilities and sectors on the basis of even vague and uncertain policy promises of the uniquely massive support of the Chinese central government is certainly already evident in other, cognate sectors, such as solar thermal or concentrated solar power (Gossens 2018). Conversely, at least insofar as it is imagined as a unilateral and radically self-interested technical fix, such complexity liberalism would seem to fit poorly with SRM deployment.

If China continues to challenge the US in terms of global climate policy leadership, as part of a wider challenge for global influence, it will become increasingly difficult for US denialists to roll back US climate commitments internationally and domestically. For US neoliberals, this is an argument for continued market-based climate policy propped up by CCS and CDR promises, legitimized by research. For US illiberals, this situation might make climate engineering promises more appealing too, and they may support SRM more willingly.

In the tension between a continued, but threatened, neoliberal regime and a budding liberalism 2.0, we can also see a dynamic that might benefit climate engineering (possibly framed as against fossil fuel use). In the short term, we might expect to see research and maybe even some deployment as an embryonic liberal 2.0 regime logic argues, perhaps not unpersuasively, for the need to explore 'all options' to reduce the potentially catastrophic effects of global warming as a position of responsibility and responsiveness to the climate emergency, not its denial or technical fix. This would thus involve rhetorical strategies to distance development of climate engineering from programmes that seek to deploy it either so as to allow unmitigated growth of fossil fuel consumption (as per the illiberal scenario) or to buy indefinite time for the market to solve the challenge of emissions and to enable marketization of the climate (as in the neoliberal one). Instead a liberal 2.0 climate engineering would seek to wed itself firmly in the public imagination with tackling climate change and decarbonisation, and with doing so 'responsibly', hence balancing the 
dangers of developing and not developing climate engineering capacities, deploying and regulating it multilaterally etc. For now, this approach would likely benefit CCS and CDR most, but SRM may also emerge, reframed as explicitly constrained (as discussed above), as a focus of such 'responsible' experimentation (e.g. Keith 2017, Low 2017).

Finally, perhaps bringing all three scenarios together, legitimacy of experimentation and advancing these technological options must be considered (Frumhoff \& Stephens 2018). A new language and promise of 'responsible' experimentation with climate engineering may well be motivated precisely by the worsening crisis of populism, its environmental irresponsibility, its political economic incompetence and the social, political, economic and financial instability it fuels. Here, then, such a dialectical inversion would suggest that development along the illiberal trajectory may fuel emergence of the China-centred liberal 2.0 scenario, but not vice versa. For the latter would move progressively towards meaningful action on climate change (benefitting at least a powerful 'some') that would serve to release some of the dissatisfaction fuelling the populist surge, while the essentially nihilistic force of populism can lead only to further grievance, division and selfdestruction.

\section{Conclusion}

This chapter has explored the impact and significance of Trump (as an indicator of and shorthand for a wider process of geopolitical change in the form of a chauvinistic populism of political economic retrenchment) regarding the co-evolution of political regimes with promises of technical fixes to the problem of global climate change. Three radically different but possible future scenarios were described and tensions among possible futures created a lens for interpreting the current moment. We identified two key dialectics, between neoliberalism and illiberalism, and between continued neoliberal (but illiberally challenged) US hegemony and budding China-centred liberalism 2.0 (and the dominant fractions of capital corresponding to each of these regimes). Both these dialectics appear conducive to prolonged attention to the climate engineering promise, whether as talk, research, or limited deployment. In a nutshell, whilst continued neoliberalism in the US and elsewhere may lead to government support for cheap-seeming climate engineering, illiberal denialism may boost non-state neoliberal efforts to support climate engineering. And whilst Chinabased liberalism 2.0 might lead to 'responsible' climate engineering efforts, even a continued US hegemony will be challenged by Chinese climate concern enough to justify US support for climate engineering as a fix.

In our previous paper (Markusson et al 2017), we analysed how the multiplicity of climate engineering, as a promise of a technical fix to climate change, has mattered for its coevolution with the neoliberal political economy regime. In this chapter, with its prospectively oriented analysis, we are also discussing how a multiplicity of possible political economy regimes matters for that coevolution. We were prompted to think beyond just a continued unfolding of the neoliberal regime by the election of Trump, and we developed a method of systematically exploring our current predicament by juxtaposing different scenarios.

Acknowledging turbulence in the current moment, we have sought to analyse emergent structures within that turbulence. This exploration does not presume scope for prediction, rather when we compare analysis from two years ago (Markusson et al 2017), we reflect on what recent events might mean for the possible co-evolutions of the political regime with climate engineering promises. Within the last two years, a newly realized illiberal challenge to the neoliberal regime has altered the 
prospects and pathways for climate engineering. The relative likelihood of the illiberal scenario vs. continued neoliberalism perhaps seems to have increased in the short-term. Although taking dialectical inversions and the turbulence of populist politics that are built into the former, this could be dramatically rebalanced in the opposite direction, e.g. given unforeseeable (possibly 'black swan') political 'events' that make Republican-led Congressional impeachment of Trump unavoidable. In any case, before we start mourning neoliberalism, it is important to acknowledge its insufficiency for promoting climate change action, at least at the scale and pace needed given the objective extent of this planetary emergency. Neoliberalism also undermined the very concept of a 'public reason', namely debate in the public sphere about matters of public good and accepted as, or at least held to account as, rational and based on empirical facts, favouring markets as epistemic arbiters. Trumpian post-truth is another aspect of how the populism for which he is current figurehead is the child of neoliberalism, and neoliberalism has now indelibly conditioned whatever comes next - whether it be a renewed invigorated neoliberalism or a new illiberal regime with autocratic rule.

Recognizing that we are currently living through a time of instability and crisis, some may assume illiberalism may be imminent. This moment is, however, unique and unpredictable. Comparing this time to the 1930s crisis, and the rise of fascism in Europe, significant differences must be acknowledged. For starters, it should be noted that at least in the US it is the opponents, not supporters, of illiberal insurgency that currently master the mainstream media and that are on the streets en masse, whether in marches for climate, science or women. While excruciatingly frustrating and certainly not without significant future jeopardy, the US in 2017 continues to resist attempts to dismantle the rule of law and constitutional government in ways that Germany in 1933 failed to. But another big difference concerns the deepening capitalist embrace and the sheer economic strength of China. In the area of climate policy, as we have argued above, a Trump regime rollback of US climate policy positions is also an opening for Chinese global positioning that the leadership of the Chinese Communist Party seems to be grasping with two hands.

With the co-evolution of climate engineering advancement and political regimes, in the short-term we might continue to expect limited research and little implementation of CCS, CDR or SRM. We expect policy debate about CDR - especially BECCS - to continue, since many experts assume it is needed to halt the most dangerous climate scenarios that may provoke panic. However, the illiberal challenge to neoliberalism has now changed the game, and this exploratory consideration suggests that there may now be more support for climate engineering research rather than less. The illiberal boost of denialism is likely to spark growing attention to SRM, and we can expect ongoing controversy over this class of technologies in domestic and international discourse. Insofar as there is increased experimentation and deployment of climate engineering technologies, a variety of different forms of backlash might be expected, from diverse political agencies and positions, and with uncertain affect. Controversy regarding climate engineering as a promise of a technical fix to climate change is unlikely to disappear as long as the climate problem continues to worsen, as long as climate activists continue to resist, and as long as fossil interests are central to political regimes. Of course, the irony here is that this dynamic and resilient tumult of forces arraigned around the issue of climate engineering may also likely shape such developments as do happen in ways that could well make it increasingly palatable, and even positively attractive, for the great many who do not engage in any depth in climate engineering issues and politics, even as it remains always essentially contested - in ways that clearly resonate with the unfolding of a liberalism 2.0.

Of course, other scenarios beyond the three articulated above are also possible. Previously we explored a fourth scenario with a strongly participative, radically democratic climate engineering, with bottom-up, local engagement with the climate. This scenario would require a re-articulation of 
both climate engineering and the climate change problem, and a focus on relatively low-tech and small-scale technologies. Martindale (2015) analyses Transition Town practices as potential democratic climate engineering, and here we have moved beyond what would currently be labelled technical fixes as such practices are typically not readily quantified and commodified (Lohmann 2005). This kind of low-tech, localist 'climate engineering' would require a radically different political regime, with small scale, local orientation, governed by a Town Hall scale public reason, and would likely require definitive moves beyond capitalism to avoid centralisation and up-scaling, and enable local, communal forms of ownership to dominate. This scenario seems highly unlikely on the time scales we have discussed here.

There are, however, also other progressive, if less utopian, visions in the literature. Olson sets out criteria for geoengineering variants that "touch gently on biological and social systems" (2012: p 30), leading him to focus on some technologies that can scale from the local to the regional. Similarly, Buck's (2012) focus on participation leads her to focus on regional terrestrial climate engineering technologies, in explicit contrast to what globally central actors can do top-down for the world as a whole. These latter versions are less uncompromisingly utopian, plausible within a still-capitalist system, and therefore more easily promoted as elements of a progressive politics of resistance against, engagement with and socio-ecological transformation of the political regimes discussed above. There is an urgent need for further analysis of the potential role of socially progressive politics in the co-evolution of climate engineering and political economies.

\section{References}

Arrighi, G. (1995) The Long Twentieth Century, Verso, London.

Bajak, A. (2018) The Dangerous Belief That Extreme Technology Will Fix Climate Change, Huffington Post, $27^{\text {th }}$ April, 2018.

Buck, H.J. (2012) Geoengineering: re-making climate for profit or humanitarian intervention? Dev. Change 43: 253-270.

Cao, L., Gao, Ch-Ch. and L-Y Zhao (2015) Geoengineering: Basic science and ongoing research efforts in China, Advances in Climate Change Research 6:188-196.

Clouse, C. (2016) Donald Trump supports 'clean coal' - but does it really have a future?, The Guardian, December 4, 2017

Crouch, C. (2011) The strange death of neoliberalism. Polity Press, Cambridge, UK.

The Economist (2017) Schumpeter: Apple should shrink its finance arm before it goes bananas, October $28^{\text {th }}$, https://www.economist.com/business/2017/10/28/apple-should-shrink-its-financearm-before-it-goes-bananas

The Economist (2018a) Some thoughts on the crisis of liberalism... and how to fix it, Bagehot blog, available at: https://www.economist.com/bagehots-notebook/2018/06/12/some-thoughts-on-thecrisis-of-liberalism-and-how-to-fix-it

The Economist (2018b) Why corporate America loves Donald Trump, May $24^{\text {th }}$, https://www.economist.com/leaders/2018/05/24/why-corporate-america-loves-donald-trump

Edney, K. and J. Symons (2014) China and the blunt temptations of geo-engineering: the role of solar radiation management in China's strategic response to climate change, The Pacific Review, 27(3): 307-332. http://dx.doi.org/10.1080/09512748.2013.807865 
ETC Group (2017) Climate change, smoke and mirrors.

http://www.etcgroup.org/sites/www.etcgroup.org/files/files/etc_geoeng_briefing_usletter_sept201 7_v2.pdf

Faber, D., Stephens JC, et al. (2017) Trump's Electoral Triumph: Class, Race, Gender, and the Hegemony of the Polluter-Industrial Complex. Capitalism Nature Socialism 28 (1): 1-15.

Factor, S. (2015) The experimental economy of geoengineering, J. Cult. Econ. 8:3, 309-324.

Federal Reserve (2017) Quarterly Report on Household Debt and Credit, May 2017, New York.

Fleming, J. (2010) Fixing the Sky: The Checkered History of Weather and Climate Control, Columbia University Press, New York.

Frumhoff, P. C. and J. C. Stephens (2018). "Toward Legitimacy in the Solar Geoengineering Research Enterprise." Philosophical Transactions of the Royal Society A 376(2119). Fuchs, Christian (2017) Donald Trump: A Critical Theory-Perspective on Authoritarian Capitalism. tripleC: Communication, Capitalism \& Critique. Open Access Journal for a Global Sustainable Information Society 15(1): 1-72.

Gill, S. R., \& Law, D. (1989) Global hegemony and the structural power of capital. International Studies Quarterly, 33(4): 475-499.

Gossens, J. (2018) Mechanisms of unrelated diversification enabling China's demonstration of nascent renewable energy technologies: the case of concentrated solar power, Presentation to the International Sustainability Transitions (IST) conference, Manchester, June $11^{\text {th }}-14^{\text {th }}, 2018$.

Guo, X. and Zheng, G. (2009) Advances in Weather Modification from 1997 to 2007 in China, Advances in Atmospheric Sciences, 26(2): 240-252

Haas, B. (2017) Climate change: China calls US 'selfish' after Trump seeks to bring back coal. Guardian, March 30, 2017.

Hao, F. (2017) China's Belt and Road still pushing coal, chinadialogue. May 12, 2017.

Hutton, W (2017) Instead of draining the swamp, Trump has become Wall Street's best buddy, Guardian, February 12, 2017.

IPCC (2014) Climate Change 2014: Synthesis Report. Contribution of Working Groups I, II and III to the Fifth Assessment Report of the Intergovernmental Panel on Climate Change, IPCC, Geneva, Switzerland.

Jessop, B. (2017) The Organic Crisis of the British State: Putting Brexit in its Place, Globalizations, 14(1):133-141.Keith, D. (2017) Toward a Responsible Solar Geoengineering Research Program, Issues in Science and Technology. 33-3.

Keith, D. and Wagner, G. (2017) Fear of solar geoengineering is healthy - but don't distort our research, The Guardian, March 29, 2017.

Lohmann, L. (2005) Marketing and making carbon dumps: commodification, calculation and counterfactuals in climate change mitigation, Sci. Cult. 14 (3): 203-235.

Lohmann, L. (2012) Financialization, commodification and carbon: the contradictions of neoliberal climate policy. Socialist register. 48(85): 107.

Low, S. (2017) Engineering imaginaries: Anticipatory foresight for solar radiation management governance. Science of the Total Environment 580: 90-104. 
Lui, K. (2017) China Is Splashing \$168 Million to Make It Rain, Fortune. Jan 24, 2017.

Lukacs, M. (2017) Trump presidency 'opens door' to planet-hacking geoengineer experiments, Guardian, March 27 2017.

Markusson, N., A. Ishii and J. C. Stephens (2011 ). "The Social and Political Complexities of Learning in CCS Demonstration Projects." Global Environmental Change 21: 293-302.

Markusson, N., Shackley, S., Evar, B. (2012) The social dynamics of carbon capture and storage: understanding CCS representations, governance and innovation. Abingdon: Earthscan. 318 p. ISBN: 978-1849713153.

Markusson, N.O., Gjefsen, M.D., Stephens, J., Tyfield, D.P. (2017) The political economy of technical fixes: the (mis)alignment of clean fossil and political regimes. Energy Research and Social Science. 23, p. 1-10.

Macnaghten, P. and Szerszynski, B. (2013) Living the global social experiment: an analysis of public discourse on solar radiation management and its implications for governance, Glob. Environ. Change 23 (2): 465-474.

Martindale, L. (2015) Understanding humans in the Anthropocene: finding answers in geoengineering and Transition Towns, Environ. Plan. D 33 (5): 907-924.

McDougall, J. (2016) No, this isn't the 1930s - but yes, this is fascism, The Conversation. $16^{\text {th }}$ Nov, 2016.

Milman, O. (2017) Trump aides abruptly postpone meeting on whether to stay in Pairs climate deal, Guardian, April 18, 2017.

Mirowski, P. (2013) Never Let a Serious Crisis Go to Waste: How Neoliberalism Survived the Financial Meltdown, Verso, London and New York.

Mitchell, T. (2011) Carbon Democracy, Political Power in the Age of Oil, Verso, London and New York. Moore, J., Chen, Y. Cui, X. et al (2016) Will China be the first to initiate climate engineering? Earth's Future, 4 (12): 588-595.

Neslen, A. (2017) US scientists launch world's biggest solar geoengineering study, Guardian, March 24, 2017.

Olson, R.L. (2012) Soft geoengineering: a gentler approach to addressing climate change, Environ. Sci. Policy Sustain. Dev. 54 (5): 29-39.

Palley, T. (2017) Trumponomics: Neocon Neoliberalism Camouflaged With Anti-globalization Circus, Social Europe. https://www.socialeurope.eu/2017/04/trumps-international-economic-policyneocon-neoliberalism-camouflaged-anti-globalization-circus/

Porter, E. (2017) To Curb Global Warming, Science Fiction May Become Fact, The New York Times, April 4, 2017.

Quiggin, J. Adamson, D. and D. Quiggin eds. (2014) Carbon Pricing: Early Experience and Future Prospects. Edward Elgar.

Royal Society (2009) Geoengineering the Climate: Science, Governance and Uncertainty, The Royal Society, London. 
Ryghaug, M. and Moe Skjølsvold, T. (2010) The Global Warming of Climate Science: Climategate and the Construction of Scientific Facts, International Studies in the Philosophy of Science, 24(3): 287307, DOI: 10.1080/02698595.2010.522411

San Diego Union-Tribune (2017) Climate Change: Trump's dramatic move deserves dramatic response, Editorial, March 17, 2017)

Sapinski, J.P. (2015) Climate Capitalism and the Global Corporate Elite Network. Environmental Sociology 1(4):268-79.

Sapinski, J.P. (2017) Corporate Climate Policy-Planning in the Global Polity: A Network Analysis. Critical Sociology Advance online publication

Schwartz, J. (2017) "Can Carbon Capture Technology Prosper under Trump", The New York Times, Jan 2, 2017.

Smith, D. (2017) Trump begins tearing up Obama's years of progress on tackling climate change, The Guardian, March 28, 2017

Smith, S. and Voss, G. (2016) Will Populism Kill Your Jetpack? The Atlantic, December 16, 2016.

Stephens, J. C. (2009). Technology Leader, Policy Laggard: Carbon Capture and Storage (CCS) Development for Climate Mitigation in the U.S. Political Context. In Caching the Carbon: The Politics and Policy of Carbon Capture and Storage. J. Meadowcroft and O. Langhelle. Cheltenham, UK, Edward Elgar Publishing: 22-49.

Stephens, J.C. (2014) Time to Stop CCS Investments and End Government Subsidies of Fossil Fuels. Wiley Interdisciplinary Reviews: Climate Change. 5: 169-173.

Stephens, J.C. (2015) Carbon Capture and Storage: A Controversial Climate Mitigation Approach The International Spectator. 50 (1), March 2015.

Temple, J. (2017) China Builds One of the World's Largest Geoengineering Research Programs, MIT Technology Review, $2^{\text {nd }}$ August, 2017.

Tyfield, D. (2014) King Coal is dead! Long live The King!: the paradoxes of Coal's resurgence in the emergence of global low-carbon societies, Theor. Cult. Soc.31 (5): 59-81.

Tyfield, D. (2016) 'Science, Innovation and Neoliberalism', The Routledge Handbook of Neoliberalism, S. Springer, K, Birch and J. Macleavy (eds), London and New York: Routledge.

Tyfield, D. (2017a) Liberalism 2.0 and the Rise of China: Global Crisis, Innovation, Urban Mobility. Routledge, London \& New York.

Tyfield, D. (2017b) Why China is serious about becoming the global leader on climate change, The Conversation, April 10, 2017.

Victor, D.G. (2008) On the regulation of geoengineering. Oxf Rev Econ Policy (2008) 24 (2): 322-336.

Volcovici, V. (2017) U.S. coal companies ask Trump to stick with Paris climate deal, Reuters, April 4, 2017.

Volcovici, V., Groom, N. and DiSavino, S. (2017) Trump declares end to 'war on coal,' but utilities aren't listening, Reuters, April 5, 2017.

Walker, B. (2016) China stokes global coal growth, Chinadialogue, September 23, 2016.

Waldmeir, P. (2018) Donald Trump opens $\$ 10 b n$ Foxconn factory in Wisconsin, Financial Times, June 29,2018 
Wallerstein, I. (2003) The Decline of American Power: The U.S. in a Chaotic World. New York: New Press.

Weng, W. and Chen, Y. (2014) A Chinese perspective on solar geoengineering, Opinion article, Geoengineering Our Climate, A Working Paper Series on the Ethics, Politics and Governance of Climate Engineering, geoengineeringourclimate.com.

Wu, W. (2017) China's 'clean coal' power: A viable model or cautionary tale? Chinadialogue, June $27^{\text {th }}, 2017$. 